\title{
GMR
}

\section{Development and validation of the first SSR markers for Mimosa scabrella Benth.}

\author{
F.A. Saiki ${ }^{1}$, A.P. Bernardi ${ }^{2}$, M.S. Reis ${ }^{2}$, H. Faoro ${ }^{3}$, E.M. Souza ${ }^{4}$, \\ F.O. Pedrosa ${ }^{4}$, A. Mantovani ${ }^{5}$ and A.F. Guidolin ${ }^{1}$ \\ ${ }^{1}$ Departamento de Agronomia, Universidade do Estado de Santa Catarina, \\ Lages, SC, Brasil \\ ${ }^{2}$ Departamento de Fitotecnia, Universidade Federal de Santa Catarina, \\ Florianópolis, SC, Brasil \\ ${ }^{3}$ Instituto Carlos Chagas-Fundação Oswaldo Cruz, Curitiba, PR, Brasil \\ ${ }^{4}$ Departamento de Bioquímica e Biologia Molecular, \\ Universidade Federal do Paraná, Curitiba, PR, Brasil \\ ${ }^{5}$ Departamento de Engenharia Florestal, \\ Universidade do Estado de Santa Catarina, Lages, SC, Brasil \\ Corresponding authors: A.F. Guidolin / F.A. Saiki \\ E-mail: altamirguidolin@gmail.com / flaviasaiki@yahoo.com.br
}

Genet. Mol. Res. 16 (1): gmr16019571

Received December 9, 2016

Accepted January 23, 2017

Published February 16, 2017

DOI http://dx.doi.org/10.4238/gmr16019571

Copyright (C) 2017 The Authors. This is an open-access article distributed under the terms of the Creative Commons Attribution ShareAlike (CC BY-SA) 4.0 License.

ABSTRACT. Mimosa scabrella Benth., popularly known as
"bracatinga", is a pioneer and endemic species of Brazil, occurring
in Mixed Ombrophilous Forest associated with Brazilian Atlantic
Rainforest biomes. It is a fast-growing tree of the Fabaceae family that
facilitates the dynamics of ecological succession. SSR development,
when there is no genome sequence, is time and labor intensive and
there are no molecular markers for $M$. scabrella. We developed and
validated the first microsatellite markers for this tetraploid species,
evaluating mother trees and progenies. Using Illumina sequencing,
we identified 290 SSR loci and 211 primer pairs. After 31 SSR loci
PCR/agarose electrophoresis selection, a subset of 11 primer pairs
was synthetized with fluorescence in the forward primer for PCR and

Genetics and Molecular Research 16 (1): gmr16019571 
capillary electrophoresis validation with leaf DNA of 33 adult and 411 progeny individuals. Polymorphic locus percentage was 36, 4 in 11 loci, 3 chloroplast SSRs, and 1 nuclear SSR. Allele number of polymorphic loci ranged from 2 to 11 alleles considering all sampling. All 11 primer pairs were also tested for cross-species amplification for five FabaceaeMimosoideae species, ranging from 2 loci transferred to Calliandra tweedii Benth. and all 11 loci transferred to Mimosa taimbensis Burkart. The assessed and validated SSR markers for M. scabrella are suitable and useful for analysis and population genetic studies.

Key words: Bracatinga; Next-generation sequencing; NuclearSSR; cpSSR; Polyploidy; Transferability

\section{INTRODUCTION}

Bracatinga (Mimosa scabrela Benth.) is a multipurpose forest species, native and endemic of South Brazil. It is a pioneer leguminous tree of rapid growth in open fields, after logging (Reitz et al., 1978) especially when burning the litter that breaks dormancy in seeds (Carneiro et al., 1982). Bracatinga is very common in rural settlements of South Brazil (Moreira et al., 2011) and economically important for timber, charcoal, fuel and energy wood, and honey production due to winter flowering (Pegoraro and Carpanezzi, 1995; Machado et al., 2002). M. scabrella is also a valuable resource for reforesting and recovering programs of degraded areas (Carneiro et al., 1982; Urbano et al., 2008). Seeds have high levels of galactomannans with great potential for biotechnological applications (Ganter and Reicher, 1999; Ughini et al., 2004; Vendruscolo et al., 2005).

There are a few articles about M. scabrella genetics. Sobierajski et al. (2006) and Moreira et al. (2011) investigated mating system using allozyme loci and found mixed mating system, predominantly outcrossing. Dahmer et al. (2011) determined tetraploid nature of the species, with chromosome number $2 \mathrm{n}=4 \mathrm{x}=52$. A major challenge for molecular characterization is the lack of sufficient DNA markers specific to M. scabrella.

Microsatellite markers, or simple sequence repeats (SSRs), unite desirable features for molecular markers: co-dominant, multi-allelic (Varshney et al., 2005) and are widely used because are simple, show high resolution and polymorphism (Squirrell et al., 2003). SSRs, once described and validated, are easily reproducible, abundant and uniformly dispersed in plant genome, so they are effective for population genetic studies, molecular ecology, and for future molecular breeding (Zhao et al., 2013). Chloroplast organelle genome is characterized by uniparental mode of inheritance, so chloroplast SSR (cpSSR) can contribute to check seed and pollen flow by comparing nuclear and chloroplast markers (Provan et al., 2001). Sequence genome knowledge is a barrier to screen SSR loci (Morris et al., 2016). Next-generation sequencing technologies can generate huge sequence data fastly, for genome mining and identification of SSR regions (Abdelkrim et al., 2009) without prior genomic library construction with SSR motif-enriched DNA (Csencsics et al., 2010). It is a promising approach for species with restricted genetic information as many native species like M. scabrella. This current study developed the first primers for $M$. scabrella microsatellites identified by next-generation sequencing, validated as a molecular marker evaluating inheritance pattern between mothers and progenies, and also tested cross-species transferability for Fabaceae-Mimosoideae species.

Genetics and Molecular Research 16 (1): gmr16019571 


\section{MATERIAL AND METHODS}

\section{Plant materials and DNA extraction}

Altogether, leaves of 444 individuals were sampled, 33 adults and 411 progenies. These 33 adult trees are in the University of Santa Catarina State, Campus of Lages. They are originated from a mixture of seedlings of three cities of Santa Catarina State: Atalanta, Urupema, and Bocaina do Sul. Five of these 33 adults were selected as mother trees to provide seeds to generate progenies. For each one of the five mother trees, it was sown 108 seeds. After 2 months of growing, some seeds did not germinate and some seedlings did not survive, the leaves of 411 health progenies were collected and analyzed with the 33 adult leaves for microsatellite validation. For cross-species transferability, leaves of five different individuals of Fabaceae-Mimosoideae species were tested: Calliandra tweedii Benth., Mimosa bimucronata (DC.) Kuntz, Mimosa taimbensis Burkart, and Parapiptadenia rigida (Benth.) Brenan. For Mimosa ramosissima Benth., leaves of two different individuals were tested.

All samples were extracted as follows: grinding and homogenizing leaves were performed with Precellys Evolution (Bertin, France) and total DNA was isolated from $30 \mathrm{mg}$ of grinded leaves with CTAB method according to Doyle and Doyle (1990). Just for proceeding with sequencing, a single sample of Mimosa scabrella DNA was purified with the Zymo ${ }^{\mathrm{TM}}$ Purification Kit (ZYMO Research, USA). The voucher specimen of the sequenced sample was included in the Herbarium Lages of Universidade do Estado de Santa Catarina, with the number LUSC 8690.

\section{Sequencing and de novo partial assembly}

Mimosa scabrella Benth. paired read sequencing was performed from genomic DNA using the MiSeq Illumina platform. Raw high throughput sequencing data and trimmed data were evaluated with FastQC to quality control check (quality value ${ }^{3} 33$ ). CLC Genomics Workbench 7.5 (CLC Bio, Denmark) was used to trim data and to form contigs.

\section{SSR identification and primer development}

Contigs were screened with SSR Locator (da Maia et al., 2008) to find microsatellite loci and design primers. Microsatellite criteria were at least three repetitions of each motif and minimum of $12 \mathrm{bp}$ (Castoe et al., 2012). Primer criteria were from 18 to $22 \mathrm{bp}$ in size, amplicon size $100-550 \mathrm{bp}$, average annealing temperature of $55^{\circ} \mathrm{C}$, at least $100 \mathrm{bp}$ of gap between microsatellites and $50 \%$ of CG. Primer quality was assessed in silico with the OligoAnalyzer 3.1 of IDT DNA website (IDT DNA Tech., Coralville, IA, USA; http://www.idtdna.com/ site) and Gene Runner (Hastings Software Inc., Hastings, NY, USA; www.generunner.net). Primer pair approval consisted in Tm difference of less than $1{ }^{\circ} \mathrm{C}$, no compound, imperfect and monomer SSR, $\Delta \mathrm{G}$ higher than $-5 \mathrm{kcal} / \mathrm{mol}$ and no palindrome (Table 1 ).

\section{Validation of SSR markers}

PCR selection was performed to test 31 primer pairs from 65 in silico approved primers (Table 1). Genomic DNA was isolated from 10 adult samples. PCR was carried out separately for each locus in a $12.5-\mu \mathrm{L}$ volume reaction with $1.5 \mathrm{ng}$ template DNA, 1X PCR buffer Tris$\mathrm{HCl}, 2.5 \mathrm{mM} \mathrm{MgCl}, 0.2 \mathrm{mM}$ dNTP mix, $0.1 \mu \mathrm{M}$ of each primer, and $0.5 \mathrm{U}$ Platinum Taq

Genetics and Molecular Research 16 (1): gmr16019571 
Table 1. Sequences of in silico approved primer pairs, synthetized unlabeled primers for PCR selection and synthetized primers for polymorphism analysis.

\begin{tabular}{|c|c|c|c|c|}
\hline Loci & Forward primer $\left(5^{\prime}-3^{\prime}\right)$ & Reverse primer $\left(5^{\prime}-3^{\prime}\right)$ & Expected size (bp) & Repeat motif \\
\hline Msc001 ${ }^{\mathrm{a}}$ & GGCATGTAACGAATTTCTTC & AATCCTTTGCAGACGACTTA & 519 & $(\mathrm{CCCG})_{3}$ \\
\hline${\mathrm{Msc} 003^{\mathrm{b}}}$ & CAATCCGTGTTTATCTAGGC & CTAGACCCTTGCTTCGTATG & 220 & $(\mathrm{GCC})_{6}$ \\
\hline Msc009 ${ }^{\mathrm{b}}$ & TGAGTAAAGGGCCTGATAAA & TACGTTTGGTGTTTGTGAGA & 521 & $($ ATATAG) 3 \\
\hline Msc017 & GCAGTTAGCTCTATCGGAGA & GACCCAGTAGATCCAGTTGA & 147 & $(\mathrm{TA})_{8}$ \\
\hline $\mathrm{Msc} 020^{\mathrm{a}}$ & TTGCCAACAGAACTTAGGAT & AAATGATGTCATGAAGAGGC & 420 & $(\mathrm{CAAT})_{3}$ \\
\hline Msc022 & AACTTGGTCCAGAGCATCTA & TATCTTGTGAGCAAACATGC & 391 & $(\mathrm{TA})_{7}$ \\
\hline $\mathrm{Msc} 023^{\mathrm{a}}$ & GCATGTTTGCTCACAAGATA & AGAATGATGACTTTGGGTTG & 505 & $(\mathrm{AAAT})_{3}$ \\
\hline Msc030 & ACAGAAACGTCGCTATCAAT & TTAACTGGGCTAGCATCTTC & 504 & $(\mathrm{AAG})_{4}$ \\
\hline Msc032 & AACTTAGCCTGAACCTCTCC & TAGGCTGGCAGAGACTAGAG & 415 & $(\mathrm{TA})_{6}$ \\
\hline$M s c 041^{b}$ & CTTAGATCAATCTCAACCCG & GAGAATTTATCATGGAAGCG & 426 & $(\text { ATTA })_{3}$ \\
\hline Msc045 ${ }^{b}$ & ATGATACGTAAGCAAGGCAT & AGTTCAAGTCACACACTCCC & 286 & $(\text { ATTAT })_{3}$ \\
\hline Msc063 $3^{\mathrm{a}}$ & ATGACACTGATTTCCTCCAG & CCAATATGGGAGATCAAAGA & 269 & $(\mathrm{GAA})_{6}$ \\
\hline Msc064 & AAATGACTATGGCTTCCTGA & CAAGCTTCTCCTAATCCAAG & 288 & $(\mathrm{AC})_{6}$ \\
\hline Msc066 ${ }^{\mathrm{a}}$ & CAGGAATTCAACAACCATCT & TATTTGAGAATCCTTGAGGG & 319 & $(\mathrm{AAC})_{5}$ \\
\hline Msc069 & GGAATGATGACTATCGAGGA & GTAAGCTCCAAGAACCACTG & 239 & $(\mathrm{TA})_{6}$ \\
\hline Msc072 ${ }^{\mathrm{b}}$ & CGCTCAAGCATCTTCTCTAT & TGTTCGTTGTGTCTTTGTGT & 436 & $(\mathrm{AACT})_{4}$ \\
\hline Msc075 & TACCCATCCTGTATATTGCC & TTTCCATAGAGCTTTCTTGC & 507 & $(\mathrm{TTA})_{4}$ \\
\hline$M s c 080^{\mathrm{a}}$ & CTATGAAAGCTTGGGTATGG & TATCTACAACCACCACCTCC & 136 & $(\mathrm{GGT})_{6}$ \\
\hline Msc098 ${ }^{\mathrm{b}}$ & CGGGAATAGAAGAGACTTCA & CTTTGTTCAATCTTTCACCC & 117 & $(\mathrm{GTTG})_{3}$ \\
\hline Msc099a & ATGAAGTGTTGATTGCTGGT & CGAATCGCAACCTAATTAAC & 504 & $(\mathrm{GAA})_{4}$ \\
\hline Msc100 & CCATCTTGGAAAGTAGGTTG & TCAACCTTAGGAGTGGAAGA & 133 & $(\mathrm{TCT})_{4}$ \\
\hline Msc102 & CTACCTGATTGTGTGTGACG & GTAGCTCAATCGCCATAATC & 302 & $(\mathrm{TA})_{9}$ \\
\hline Msc105 & AGTATATGCGACGTATGGCT & CCTCAATGTTGGAGGAGTAA & 476 & $(\mathrm{TA})_{7}$ \\
\hline Msc106 & ACAACCAGAGGTTCACAGAC & TTGAGAAAGAAATCCTGGAC & 397 & $(\mathrm{TA})_{6}$ \\
\hline Msc108 & CACATGTTGCTCACGTTTAC & TCCCATGTGTTCACACTAAA & 520 & $(\mathrm{CT})_{8}$ \\
\hline $\mathrm{Msc} 120^{\mathrm{a}}$ & TGATGAGTAAGTATGCGTCG & GAAATTCTTCTCCCAGGACT & 395 & $(\mathrm{CCT})_{5}$ \\
\hline $\operatorname{Msc121^{\mathrm {a}}}$ & TGGTAAAGAAGGGAGAATGA & AAATTCTGTCCCTGTTGTTG & 426 & $(\mathrm{TAAA})_{3}$ \\
\hline $\mathrm{Msc} 124^{\mathrm{b}}$ & TCTTGCTCAGACCGATAAAT & AGGATGGGTAGATGTCACAG & 292 & $(\mathrm{ATCA})_{3}$ \\
\hline $\operatorname{Msc} 127^{\mathrm{a}}$ & GTCCGAGTTTCACCAATTTA & TGCACAAACTTAATGGAGAC & 235 & $(\text { TTTA })_{3}$ \\
\hline Msc138 & CAACGGATCTATTCTAACGG & GAGCATTGAGAGTGGAAGAG & 174 & $(\mathrm{GAT})_{4}$ \\
\hline Msc151 & AATATGGGCACATCAAAGTC & TCTCCTCCTTGTATGCCTAA & 131 & $(\mathrm{CAT})_{4}$ \\
\hline Msc158 & ATTGTAGACGACGGTGAATC & CATCCCTAATTCCTCAATCA & 496 & $(\mathrm{AT})_{9}$ \\
\hline Msc159 & TCCGCTGTTTACTCTGAGAT & GTGTTCCTATCTTGCTTTCG & 200 & $(\text { TGCTT })_{3}$ \\
\hline$M s c 160^{\mathrm{b}}$ & ATCGTATGAGCTCGCATC & TCTATACAGATTGCCATCCC & 101 & $(\mathrm{TCT})_{5}$ \\
\hline Msc161 ${ }^{\mathrm{b}}$ & AGCTCTCTTCTTCGTCCTTT & GCCATATTCAAACGGATCTA & 112 & $(\mathrm{TCT})_{5}$ \\
\hline Msc165 & CCTCCAACCCTCTTCTAACT & CACAATACGAGATGGTTCAA & 247 & $(\mathrm{TG})_{7}$ \\
\hline Msc173 & ACGACATTTCATTTCCTGAG & CTCTCCTCAACCTCACTCTG & 171 & $(\mathrm{TGA})_{4}$ \\
\hline $\mathrm{Msc174}^{\mathrm{a}}$ & CAGAGTGAGGTTGAGGAGAG & CCCAATTAAGCTGCAATATC & 467 & $(\text { ATTT })_{3}$ \\
\hline Msc175 & TCATATGTCTTGAGCATCCA & ACGAGACAAGAGACCAAGAA & 256 & $(\mathrm{TTG})_{4}$ \\
\hline Msc179 & TCATCTCATCTCACCACTGA & TTCAACTCAAGTGCATCAAG & 194 & $(\mathrm{TGA})_{4}$ \\
\hline Msc184 & CCAAGATAATTCCCTCAGACT & CATCCTCCTTATGATTCGAG & 146 & $(\mathrm{AAG})_{4}$ \\
\hline Msc187 & GAAAGGTACCCAGAGGCTAT & ACCTGATTGTTTGTGTGGTT & 130 & $(\mathrm{AT})_{9}$ \\
\hline Msc193 & GACCGGAGGGAGTATTATTT & GGAATTGCGTTACATGAGAT & 137 & $(\mathrm{AT})_{8}$ \\
\hline Msc196 & TAGTTCTGGAAGCTATGGGA & TGCCCTTGAATAGAAACTGT & 447 & $(\mathrm{GCA})_{4}$ \\
\hline Msc198 & AGATGCAATATTAGGGCTCA & GATCTCCTTCTACACCCACA & 190 & $(\mathrm{CCA})_{4}$ \\
\hline Msc199a & CACAATTCCACTCAATGTCA & ATTGTGAAATGGTTAGGTGC & 208 & $(\mathrm{CAAT})_{3}$ \\
\hline Msc200 & CACATCGGTTCCTAAGACAT & AGGGAGAGTGAGGATAAAGG & 315 & $(\mathrm{ATT})_{4}$ \\
\hline Msc204 & ATCAGCTCGAATTTAGGGTT & TCAAAGGGATGATGATTAGG & 121 & $(\mathrm{TTC})_{4}$ \\
\hline Msc206 & ATGAGTGGGTTAGCAGAGTG & TGAATGCAAGTCTGTGTGAT & 189 & $(\mathrm{AT})_{8}$ \\
\hline $\operatorname{Msc} 217^{b}$ & TGAGTCGGAGCTATCATCTT & AGAGGTCCAGAGATAAAGGG & 161 & $(\mathrm{CTT})_{5}$ \\
\hline Msc218 & AAAGAAACTCAAGGTCCCTC & TCCTCATCATCCTCAGACTC & 179 & $(\mathrm{AGA})_{5}$ \\
\hline Msc2199 & GATTATGGCTTGCTTCTGTC & CCAATGTTACTCAAGCCAAT & 175 & $(\mathrm{GCTT})_{3}$ \\
\hline Msc220 & TCTAACTCTTCTGCCTCAGC & AAGAAGATTGTGCTGTCGAT & 427 & $(\mathrm{TTC})_{4}$ \\
\hline Msc225 & ACAAACCAAGAAACACCAAC & GATGACTTAGAACGGGATCA & 408 & $(\mathrm{AT})_{6}$ \\
\hline Msc229 & GAGAAAGGATATGATGCAGG & GTTGCTCGGAAATTATAAGG & 140 & $(\text { AATA })_{4}$ \\
\hline Msc230 & CATATGTCAAATGCCTTTCC & ATAAATTGACTGATGGGTGC & 151 & $(\mathrm{TA})_{7}$ \\
\hline $\operatorname{Msc} 231^{\mathrm{a}}$ & GTGGATTGTTAGGCATGAAT & AATGCAAGAGTGATATGGGT & 504 & $(\mathrm{CAAAA})_{3}$ \\
\hline Msc240 & GAAATGTAGTTGGTTGACCG & ATTCTTCTTCTCCTTCGTCC & 239 & $(\mathrm{CCT})_{4}$ \\
\hline Msc248 & GTGATTGGGATATTGAGGAA & GGTCCCTGTCTACAATCAGA & 166 & $(\mathrm{CGGC})_{3}$ \\
\hline Msc253a & TGTTGAGAGTGTGCATTCAT & GTTGTATTGATGGAAAGGCT & 321 & $(\text { CATTC })_{3}$ \\
\hline Msc255 & CAAAGCAAATCAAGTGGC & CCAGCAGTGACTACAACAGA & 241 & $(\mathrm{TGT})_{4}$ \\
\hline Msc256 ${ }^{\mathrm{a}}$ & GATTGATCTCATTGGACTGG & TCATTTCTTCATCCTTCACC & 493 & $(\mathrm{AAGA})_{3}$ \\
\hline Msc259 & TCCCTGATTGAAATGAAGAC & AGTTGAGAGTTGAGAAGGAAGA & 219 & $(\mathrm{TG})_{6}$ \\
\hline Msc266 ${ }^{\mathrm{a}}$ & GCTGCTTATCTTTCTCTTGG & GTGCCTGACACATACCTCTT & 219 & $(\mathrm{GAT})_{5}$ \\
\hline Msc267 & AGAAGATCAAGGAAAGGAGC & ATAAGTTCAATGGGAGCAGA & 256 & $(\mathrm{AAG})_{4}$ \\
\hline
\end{tabular}

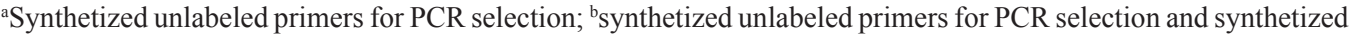
primers for polymorphism analysis.

Genetics and Molecular Research 16 (1): gmr16019571 
DNA Polymerase (Invitrogen). Amplification program was $95^{\circ} \mathrm{C}$ for $2 \mathrm{~min} ; 35$ cycles of 45 $\mathrm{s}$ at $95^{\circ} \mathrm{C}, 1 \mathrm{~min}$ at $55^{\circ} \mathrm{C}$, and $2 \mathrm{~min}$ at $72^{\circ} \mathrm{C}$; and a final extension of $5 \mathrm{~min}$ at $72^{\circ} \mathrm{C}$ on Veriti thermocyclers (Applied Biosystems). The PCR products were analyzed on 2\% agarose gels. From 31 SSR locus PCR selections, 11 loci were then assessed for polymorphism in 444 samples of Mimosa scabrella.

\section{Genotyping using Multiplex Panels and polymorphism analysis validation}

The Multiplex Panels were developed with Autodimer (Vallone and Butler, 2004) and Multiplex Manager (Holleley and Geerts, 2009) with up to four loci per panel (Table 2). PCRs were performed in a 12.5 - to $25-\mu \mathrm{L}$ volume reaction with $1 \mathrm{ng}$ template DNA, 1X PCR buffer Tris- $\mathrm{HCl}, 2.5 \mathrm{mM} \mathrm{MgCl}, 0.2 \mathrm{mM}$ dNTP mix, 0.05 to $0.12 \mu \mathrm{M}$ of each primer (Table 2) and 1 U Platinum Taq DNA Polymerase (Invitrogen). DMSO (10\%) was added for Msc003 and Msc161. PCR amplification was also performed on Veriti thermocyclers (Applied Biosystems) under the following conditions: $95^{\circ} \mathrm{C}$ for $10 \mathrm{~min} ; 25$ cycles of $45 \mathrm{~s}$ at $95^{\circ} \mathrm{C}, 1 \mathrm{~min}$ at $55^{\circ}$ $56^{\circ} \mathrm{C}$, and $2 \mathrm{~min}$ at $72^{\circ} \mathrm{C}$; and a final extension of $30 \mathrm{~min}$ at $72^{\circ} \mathrm{C}$. Fluorescent dyes of each forward primer, primer concentration, and annealing temperature are described in Table 2. Fluorescently labeled PCR products were separated by capillary electrophoresis using the ABI 3130 Genetic Analyzer (Applied Biosystems) with internal size standard GeneScan600 LIZ (Applied Biosystems). Peak interpretation, allele size calling and genotyping were performed with the Gene Mapper ${ }^{\circledR}$ software ID-X v. 1.2 (Applied Biosystems). Descriptive statistics, for the nuclear SSR marker, like allelic richness, the number of alleles at a locus $\left(N_{\mathrm{A}}\right)$; genotypic richness, the number of genotypes with four alleles per locus $(\mathrm{G})$; the observed and expected heterozygosities $\left(H_{\mathrm{O}}\right.$ and $\left.H_{\mathrm{E}}\right)$ and fixation index $(\mathrm{F})$ were all calculated using Autotet (Thrall and Young, 2000) assuming autopolyploidy. $H_{\mathrm{E}}$ and $\mathrm{F}$ were computed under random mating and chromosome segregation $\left[H_{\mathrm{F}}(\mathrm{Ce})\right]$ and $[\mathrm{F}(\mathrm{Ce})]$, and under random mating and some level of chromatid segregation $\left[H_{\mathrm{E}}(\mathrm{Cd})\right]$ and $[\mathrm{F}(\mathrm{Cd})]$, considering maximum double reduction with $\alpha=1 / 7$. For cpSSR, haplotype frequencies were calculated using GenAlEx 6.5 (Peakall and Smouse, 2012).

\begin{tabular}{|c|c|c|c|c|c|c|c|c|}
\hline Locus & Multiplex panel & Forward primer dye & Allele size (bp) & $\begin{array}{c}\text { Primer } \\
\text { concentration }(\mu \mathrm{M})\end{array}$ & $\mathrm{Ta}\left({ }^{\circ} \mathrm{C}\right)$ & BLASTn top hit & E value & \begin{tabular}{|c|} 
GenBank \\
accession No
\end{tabular} \\
\hline Msc098* & 1 & VIC & 113 & 0.05 & 56 & No hit & - & KY082898 \\
\hline $\mathrm{Msc} 045$ & $\frac{1}{1}$ & VIC & $267-283$ & 0.05 & 56 & Chloroplast genome (Acacia exocarpoides) & $3 \mathrm{E}-114$ & KY310532 \\
\hline $\mathrm{Msc124}$ & 1 & FAM & $286-300$ & 0.05 & 56 & Chloroplast genome (Pararchidendron pruinosum) & $2 \mathrm{E}-136$ & KY310534 \\
\hline Msc217* & 1 & FAM & 156 & 0.05 & 56 & No hit & - & KY310536 \\
\hline Msc229* & 2 & PET & 138 & 0.11 & 56 & No hit & - & KY034416 \\
\hline Msc041* & $\frac{2}{2}$ & NED & 422 & 0.07 & 56 & Chloroplast genome (Prosopis glandulosa) & $3 \mathrm{E}-100$ & KY310533 \\
\hline Msc009 & 2 & FAM & $499-514$ & 0.12 & 56 & Chloroplast genome (Acacia formidabilis) & $1 \mathrm{E}-40$ & KY271088 \\
\hline Msc072* & 2 & VIC & 430 & 0.07 & 56 & No hit & - & KY273304 \\
\hline Msc161* & 3 & NED & 108 & 0.2 & 56 & No hit & - & KY310537 \\
\hline Msc003 & 3 & NED & $195-224$ & 0.1 & 56 & No hit & - & KY310535 \\
\hline Msc160* & Single & FAM & 95 & 0.05 & 55 & No hit & - & KY310538 \\
\hline
\end{tabular}

*Monomorphic loci; $\mathrm{Ta}=$ annealing temperature.

\section{RESULTS AND DISCUSSION}

\section{Characterization of microsatellites and validation for Mimosa scabrella}

Illumina paired-end sequencing generated a total of 1,431,034 reads with 237,704,384 bases. After trimming and quality control read checks, 42,546 contigs were assembled.

Genetics and Molecular Research 16 (1): gmr16019571 
Contigs screening generated 290 SSR loci, trinucleotide repeats were the most common $(32.4 \%)$, followed by tetranucleotide $(23.15 \%)$, dinucleotide $(19.0 \%)$, mononucleotide $(17.6 \%)$, pentanucleotide $(6.25 \%)$, and hexanucleotide $(1.7 \%)$ repeats. The number of perfect, imperfect, and compound motif repeats corresponds to 252, 2, and 16 loci. From all SSR loci identified, we designed 211 primer pairs, 65 primer pairs were approved after in silico primer quality assessment, and a subset of 31 were synthesized. All 31 primer pairs were tested on agarose, 19 generated amplicons in the expected size, and from these, 11 primer pairs were synthetized with fluorescent dyes in forward primer. All samples successfully amplified and showed at least one allele in common between mother trees and progeny samples in all 11 markers. Based on capillary electrophoresis data for the $444 \mathrm{M}$. scabrella samples, 4 loci were polymorphic $(\mathrm{P}=36 \%)$ in adult and progeny individuals: Msc009, Msc045, Msc124, and Msc003, with allele richness (A) of 4, 3, 2, and 11, respectively, considering all sampling. These polymorphic markers are hexa-, penta-, tetra-, and trinucleotide motifs. A similarity search of amplicon contigs was conducted using BLASTn with E value cutoff of $1 \times 10^{-5}$ (Table 2) Of the 11 markers, Msc009, Msc041, Msc045, and Msc124 sequences showed significant similarity with chloroplast genomes of some Mimosoideae species and all samples of these markers displayed only one allele per sample and the same allele between mother trees and progenies, revealing maternal inheritance of chloroplast genome for M. scabrella. Msc003 displayed from one to four alleles per sample, showing its tetraploid nature, as described by Dahmer et al. (2011). Only identified allele peaks were considered for heterozygote genotype, without considering the allelic dosage for incomplete heterozygotes (Narayan et al., 2015).

Significant departure from Hardy-Weinberg equilibrium was detected at Msc003 locus $(\mathrm{P}<0.001)$ under chromosome and chromatid segregation for adults and progenies. Allele richness, genotypic richness, and $H_{\mathrm{O}}$ were 5,4 , and 0.394 for adults and for progenies they were 11, 16, and 0.309. For adults, under random mating and chromosome segregation, $\mathrm{F}(\mathrm{Ce})$ and $H_{\mathrm{E}}(\mathrm{Ce})$ were 0.478 and 0.175 . Considering random mating and some level of chromatid segregation, $\mathrm{F}(\mathrm{Cd})$ and $H_{\mathrm{E}}(\mathrm{Cd})$ were 0.446 and 0.116 . For progenies, $\mathrm{F}(\mathrm{Ce})$ was $0.296, H_{\mathrm{E}}(\mathrm{Ce})$ $0.438, \mathrm{~F}(\mathrm{Cd}) 0.245$, and $H_{\mathrm{E}}(\mathrm{Cd}) 0.409$.

Four different haplotypes were found for Msc009, Msc045, and Msc124 cpSSRs, two in common between adult and progeny groups, and the other two were private to the adult group. The haplotype 1, formed by the alleles $514 \mathrm{bp}$ (Msc009), $283 \mathrm{bp}$ (Msc045), and $286 \mathrm{bp}$ (Msc124), was the most common both for adult and progeny groups with frequencies of 0.788 and 0.762 . The haplotype 2, formed by 499,274 , and $300 \mathrm{bp}$ alleles, was the second most common, with frequencies of 0.152 and 0.238 for adult and progeny groups, respectively. Haplotype 3, formed by 507, 267, and 286 bp alleles, and haplotype 4 formed by 502, 267, and 286 bp alleles had only one occurrence in adults, both with frequency of 0.030 . Polymorphism detection in chloroplast genome is limited due to low mutation rate and does not recombine (Provan et al., 2001). Informative chloroplast microsatellite of non-model species can be time intensive (McPherson et al., 2013) and first microsatellites developed for M. scabrella included three polymorphic cpSSRs.

The 11 SSR markers were $100 \%$ cross-amplified in five Mimosoideae species, ranging from two loci in Calliandra tweedii Benth. to all 11 loci in M. taimbensis Burkart (Table 3). Msc003 marker displayed polymorphism for M. taimbensis.

Next-generation sequencing has enabled detection of many SSR loci and marker development for nuclear and chloroplast sequences. The validated SSR set developed in this study has the potential to be applied for population genetic studies, will enhance molecular

Genetics and Molecular Research 16 (1): gmr16019571 
research on the species for marker-assisted selection and develop conservation strategies for this highly human managed species. The validated SSR set can also be used in other FabaceaeMimosoideae species because of its high cross-amplification and as SSR reference for other polyploidy species. However, most of the microsatellite markers obtained in the present study still need to be further validated.

Table 3. Cross-species transferability test of Mimosa scabrella microsatellites for five Fabaceae-Mimosoideae family species.

\begin{tabular}{l|c|c|c|c|c}
\hline Loci & CTW $(\mathrm{N}=5)$ & MBM $(\mathrm{N}=5)$ & MRM $(\mathrm{N}=2)$ & MTB $(\mathrm{N}=5)$ & PTR $(\mathrm{N}=5)$ \\
\hline Msc229 & - & - & + & + & - \\
\hline Msc041 & - & - & + & + & + \\
\hline Msc009 & - & + & - & + & + \\
\hline Msc072 & - & - & + & + & + \\
\hline Msc160 & - & + & + & + & - \\
\hline Msc045 & + & - & - & + & + \\
\hline Msc098 17 & - & - & + & + & + \\
\hline Msc124 & - & + & - & + & + \\
\hline Msc161 & + & - & - & + & + \\
\hline Msc003 & - & - & + & - \\
\hline
\end{tabular}

$\mathrm{CTW}=$ Calliandra tweedii Benth.; MBM = Mimosa bimucronata $(\mathrm{DC}.) \mathrm{Kuntz} ; \mathrm{MRM}=$ Mimosa ramosissima Benth.; MTB = Mimosa taimbensis Burkart; PTR = Parapiptadenia rigida (Benth.) Brenan; $\mathrm{N}=$ number of individuals.

\section{Conflicts of interest}

The authors declare no conflict of interest.

\section{ACKNOWLEDGMENTS}

The authors thank Fundação de Amparo à Pesquisa e Inovação do Estado de Santa Catarina (FAPESC) for financial support.

\section{REFERENCES}

Abdelkrim J, Robertson B, Stanton JAL and Gemmell N (2009). Fast, cost-effective development of species-specific microsatellite markers by genomic sequencing. Biotechniques 46: 185-192. http://dx.doi.org/10.2144/000113084

Carneiro RM, Almeida AR, Jr., Kageyama PY and Dias IS (1982). Importância da dormência das sementes na regeneração da bracaatinga - Mimosa scabrella Benth. IPEF 149: 1-9.

Castoe TA, Poole AW, de Koning AP, Jones KL, et al. (2012). Rapid microsatellite identification from Illumina paired-end genomic sequencing in two birds and a snake. PLoS One 7: e30953. http://dx.doi.org/10.1371/journal.pone.0030953

Csencsics D, Brodbeck S and Holderegger R (2010). Cost-effective, species-specific microsatellite development for the endangered Dwarf Bulrush (Typha minima) using next-generation sequencing technology. J. Hered. 101: 789-793. http://dx.doi.org/10.1093/jhered/esq069

Dahmer N, Simon MF, Schifino-Wittmann MT, Hughes CE, et al. (2011). Chromosome numbers in the genus Mimosa L.: cytotaxonomic and evolutionary implications. Plant Syst. Evol. 291: 211-220. http://dx.doi.org/10.1007/s00606$\underline{010-0382-2}$

Doyle JJ and Doyle JL (1990). Isolation of Plant DNA from Fresh Tissue. Focus 12: 13-15.

Ganter JLMS and Reicher F (1999). Water-soluble galactomannans from seeds of Mimosaceae spp. Bioresour. Technol. 68: 55-62. http://dx.doi.org/10.1016/S0960-8524(98)00078-9

Holleley CE and Geerts PG (2009). Multiplex Manager 1.0: a cross-platform computer program that plans and optimizes multiplex PCR. Biotechniques 46: 511-517. http://dx.doi.org/10.2144/000113156

Genetics and Molecular Research 16 (1): gmr16019571 
Machado SA, Tonon AEN, Figueiredo Filho A and Oliveira EB (2002). Evolução da área basal e do volume em bracatingais nativos submetidos a diferentes densidades iniciais e em diferentes sítios. Floresta 32: 61-74. http:// dx.doi.org/10.5380/rf.v32i1.2349

da Maia LC, Palmieri DA, de Souza VQ, Kopp MM, et al. (2008). SSR locator: tool for simple sequence repeat discovery integrated with primer design and PCR simulation. Int. J. Plant Genomics 2008: 412696. http://dx.doi. org $/ 10.1155 / 2008 / 412696$

McPherson H, van der Merwe M, Delaney SK, Edwards MA, et al. (2013). Capturing chloroplast variation for molecular ecology studies: a simple next generation sequencing approach applied to a rainforest tree. BMC Ecol. 13: 8. http:// dx.doi.org/10.1186/1472-6785-13-8

Moreira PA, Steenbock W, Peroni N and Reis MS (2011). Genetic diversity and mating system of bracatinga (Mimosa scabrella) in a re-emergent agroforestry system in southern Brazil. Agrofor. Syst. 83: 245-256. http://dx.doi. org/10.1007/s10457-011-9428-x

Morris AB, Scalf C, Burleyson A, Johnson LT, et al. (2016). Development and characterization of microsatellite primers in the federally endangered Astragalus bibullatus (Fabaceae). Appl. Plant Sci. 4: 1500126. http://dx.doi.org/10.3732/ apps.1500126

Narayan L, Dodd RS and O'Hara KL (2015). A genotyping protocol for multiple tissue types from the polyploid tree species Sequoia sempervirens (Cupressaceae). Appl. Plant Sci. 3: 1400110. http://dx.doi.org/10.3732/apps.1400110

Peakall R and Smouse PE (2012). GenAlEx 6.5: genetic analysis in Excel. Population genetic software for teaching and research--an update. Bioinformatics 28: 2537-2539. http://dx.doi.org/10.1093/bioinformatics/bts460

Pegoraro A and Carpanezzi AA (1995). Avaliação do potencial melífero da Bracatinga. Ver. Setor de Cienc. Agr. 14: $167-172$.

Provan J, Powell W and Hollingsworth PM (2001). Chloroplast microsatellites: new tools for studies in plant ecology and evolution. Trends Ecol. Evol. (Amst.) 16: 142-147. http://dx.doi.org/10.1016/S0169-5347(00)02097-8

Reitz R, Klein RM and Reis A (1978). Projeto madeira de Santa Catarina. Herbário Barbosa Rodrigues, Itajaí.

Sobierajski GR, Kageyama PY and Sebbenn AM (2006). Sistema de reprodução em nove populações de Mimosa scabrella Benth. Sci. Forum 71: 37-49.

Squirrell J, Hollingsworth PM, Woodhead M, Russell J, et al. (2003). How much effort is required to isolate nuclear microsatellites from plants? Mol. Ecol. 12: 1339-1348. http://dx.doi.org/10.1046/j.1365-294X.2003.01825.x

Thrall PH and Young A (2000). AUTOTET: a program for analysis of autotetraploid genotypic data. J. Hered. 91: 348349. http://dx.doi.org/10.1093/jhered/91.4.348

Ughini F, Andreazza IF, Ganter JLMS and Bresolin TMB (2004). Evaluation of xanthan and highly substituted galactomannan from M. scabrella as a sustained release matrix. Int. J. Pharm. 271: 197-205. http://dx.doi. org/10.1016/j.ijpharm.2003.11.011

Urbano E, Machado AS, Figueiredo Filho A and Koehler HS (2008). Equações para estimar o peso de carbono fixado em árvores de Mimosa scabrella Bentham (Bracatinga) em povoamentos nativos. Cerne 14: 194-203.

Vallone PM and Butler JM (2004). AutoDimer: a screening tool for primer-dimer and hairpin structures. Biotechniques 37: 226-231.

Varshney RK, Graner A and Sorrells ME (2005). Genic microsatellite markers in plants: features and applications. Trends Biotechnol. 23: 48-55. http://dx.doi.org/10.1016/j.tibtech.2004.11.005

Vendruscolo CW, Andreazza IF, Ganter JLMS, Ferrero C, et al. (2005). Xanthan and galactomannan (from M. scabrella) matrix tablets for oral controlled delivery of theophylline. Int. J. Pharm. 296: 1-11. http://dx.doi.org/10.1016/j. ijpharm.2005.02.007

Zhao Y, Williams R, Prakash CS and He G (2012). Identification and characterization of gene-based SSR markers in date palm (Phoenix dactylifera L.). BMC Plant Biol. 12: 237. http://dx.doi.org/10.1186/1471-2229-12-237

Genetics and Molecular Research 16 (1): gmr16019571 